\title{
COVID-19 vaccine hesitancy worldwide: a systematic review of vaccine acceptance rates
}

\author{
Malik Sallam ${ }^{1,2, *}$ \\ 1 Department of Pathology, Microbiology and Forensic Medicine, School of Medicine, the University of Jor- \\ dan, Amman 11942, Jordan; malik.sallam@ju.edu.jo (M.S.) \\ 2 Department of Clinical Laboratories and Forensic Medicine, Jordan University Hospital, Amman 11942, \\ Jordan \\ * Correspondence: malik.sallam@ju.edu.jo; Tel: +962-79-184-5186 (M.S.)
}

\begin{abstract}
Utility of vaccine campaigns to control coronavirus disease 2019 (COVID-19) is not merely dependent on vaccine efficacy and safety. Vaccine acceptance among the general public and the healthcare workers, appears to have a decisive role for successful control of the pandemic. The aim of this review was to provide an up-to-date assessment of COVID-19 vaccination acceptance rates worldwide. A systematic search of the peer-reviewed English survey literature indexed in PubMed was done on December 25, 2020. Results from 30 studies, met the inclusion criteria and formed the basis for final COVID-19 vaccine acceptance estimates. Results of an additional recent survey from Jordan and Kuwait was considered in this review as well. Survey studies on COVID-19 vaccine acceptance rates were found from 33 different countries. Among adults representing the general public, the highest COVID-19 vaccine acceptance rates were found in Ecuador (97.0\%), Malaysia (94.3\%), Indonesia (93.3\%) and China (91.3\%). On the other hand, the lowest COVID-19 vaccine acceptance rates were found in Kuwait (23.6\%), Jordan (28.4\%), Italy (53.7), Russia (54.9\%), Poland (56.3\%), US (56.9\%), and France (58.9\%). Only eight surveys among healthcare workers (doctors, nurses) were found, with vaccine acceptance rates ranging from $27.7 \%$ in the Democratic Republic of the Congo to $78.1 \%$ in Israel. In a majority of survey studies among the general public (62\%), the acceptance of COVID-19 vaccination showed a level of $\geq 70 \%$. Low rates of COVID-19 vaccine acceptance were reported in the Middle East, Russia, Africa and several European countries. This could represent a major problem in the global efforts that aim to control the current COVID-19 pandemic. More studies are recommended to address the scope of COVID-19 vaccine hesitancy. Such studies are particularly needed in the Middle East Africa, Eastern Europe, Central Asia, Middle and Latin America.
\end{abstract}

Keywords: Vaccine hesitancy; Vaccine acceptance; Anti-vaccination; COVID-19; Coronavirus; SARS-CoV-2; Vaccine rejection

\section{Introduction}

Based on Strategic Advisory Group of Experts on Immunization (SAGE), vaccine hesitancy is the term used to describe: "delay in acceptance or refusal of vaccination despite availability of vaccination services" [1]. Factors that affect the attitude towards acceptance of vaccination include complacency, convenience and confidence [1,2]. Complacency denotes the low perception of the disease risk; hence, vaccination deemed unnecessary. Confidence refers to the trust in vaccination safety, effectiveness, besides the competence of the healthcare systems. Convenience entails the availability, affordability and delivery of vaccines in a comfortable context [2].

The complex nature of motives behind vaccine hesitancy can be analyzed using the epidemiologic triad of environmental, agent and host factors [3,4]. Environmental factors include public health policies, social factors and the messages spread by media [5-7]. The agent (vaccine and disease) factors involve the perception of vaccine safety and 
effectiveness besides the perceived susceptibility to the disease [7-9]. Host factors are dependent on knowledge, previous experience, educational and income levels [4,10].

The current coronavirus disease 2019 (COVID-19) pandemic does not seem to show any signs of decline, with more than 1.7 million deaths and more than 80 million reported cases worldwide, as of December 27, 2020 [11,12]. The ebb and flow of COVID-19 cases can be driven by human factors including attitude towards physical distancing and protective measures, while viral factors are driven by mutations that commonly occur in severe acute respiratory syndrome coronavirus 2 (SARS-COV-2) genome [13-18]. The viral factors can be particularly of high relevance considering the recent reports of resurgence in COVID-19 infections in UK due to a new variant of the virus [19].

The global efforts to lessen the effects of the pandemic, and to reduce the health and socio-economic impact relies to a large extent on the preventive efforts [20,21]. Thus, huge efforts by the scientific community and pharmaceutical industry backed by governments' support, were directed towards developing efficacious and safe vaccines for SARS-CoV2 [22]. These efforts were manifested by approval of three vaccines, in addition to more than 60 vaccine candidates in clinical trials. Moreover, more than 170 COVID-19 vaccine candidates are in the pre-clinical phase [23].

Despite the huge efforts made to achieve successful COVID-19 vaccines, a major hindrance can be related to vaccine hesitancy towards the approved and prospective COVID19 vaccination [24]. To identify the scope of this problem, this systematic review aimed to assess the acceptance rates for COVID-19 vaccine(s) in different countries worldwide.

\section{Materials and Methods}

This review was conducted following the PRISMA guidelines [25].

Published papers in PubMed/Medline that aimed at evaluating COVID-19 vaccine hesitancy/vaccine acceptance using a survey/questionnaire were eligible for inclusion in this review.

Only studies in English language that met the inclusion criteria were considered in this review.

Search was done as of December 25, 2020 using the following strategy: ((COVID* vaccine $^{*}$ hesitancy[Title/Abstract]) OR (COVID* vaccine acceptance[Title/Abstract])) OR (COVID $^{*}$ vaccin* hesitanc*[Title/Abstract])) OR (COVID* intention to vaccin* [Title/Abstract]) OR (COVID* vaccin* accept*[Title/Abstract]) AND (2020:2020[pdat]).

Screening of titles and abstracts was conducted, followed by data extraction for the following items: Date of survey, country/countries in which the survey was conducted, target population for survey (e.g. general public, healthcare workers, students), total number of respondents, and COVID-19 vaccine acceptance rate (which included the number of respondents who answered: agree/somewhat/completely agree/leaning towards yes/definitely yes).

\section{Results}

A total of 178 records were identified, and following the screening process, a total of 30 articles were included in this review (Figure 1). In addition, data collected in an unpublished manuscript that surveyed the general public residing in Jordan and Kuwait were added to the final analysis [26]. 


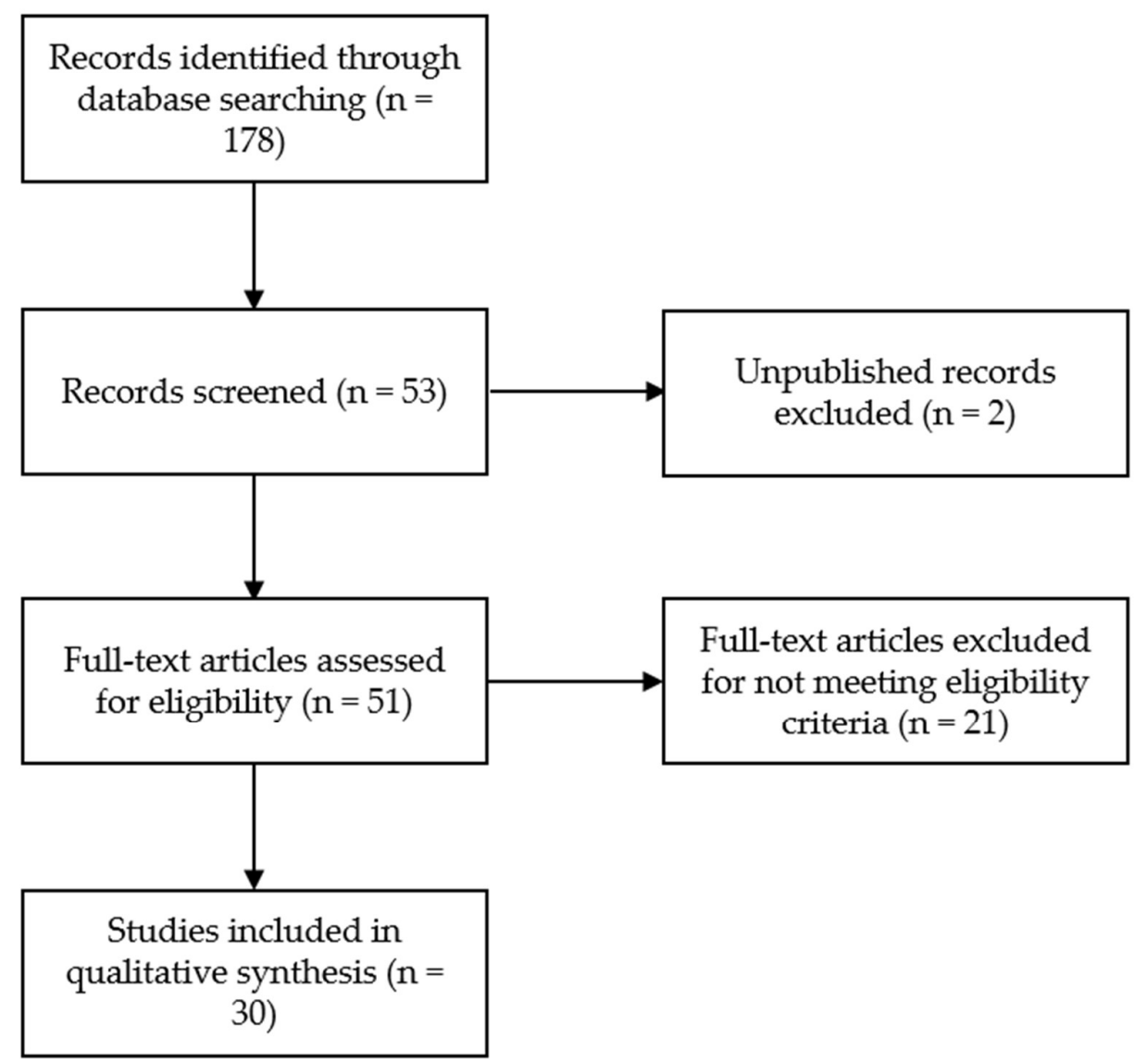

Figure 1. Flow chart of the study selection process

\subsection{Characteristics of the papers included in this review}

A total of 30 published papers were analyzed in this review, with an additional unpublished manuscript that focused on COVID-19 vaccine acceptance in Jordan and Kuwait to yield a total of 31 studies. These studies comprised surveys on COVID-19 vaccine acceptance from a total of 33 different countries. Surveys were done most commonly in UK ( $n=6)$, followed by France \& US ( $n=5$, for each country), and China \& Italy $(n=4$, for each country). Dates of survey distribution ranged from February 2020 until December 2020. A few studies were conducted in more than one country; with the study by Lazarus et al involving 19 countries and the study by Neumann-Böhme et al involving seven European countries [27,28].

Stratified per country, a total of 60 surveys were found with the largest sample size $(\mathrm{n}=5114)$ in the study conducted in UK by Freeman et al, while the smallest sample size $(\mathrm{n}=123)$ was found in the study conducted in Malta by Gretch et al among general practitioners and trainees $[29,30]$. Out of these 60 surveys, 47 were among the general public, eight surveys were among healthcare workers (doctors, nurses, or others), three surveys were among parents/guardians and two surveys were among University students (Table 1). Surveys were most commonly conducted in June or July $(23 / 60,38 \%)$, followed by March or April (20/60, 33\%). 
Table 1. COVID-19 acceptance rates divided by the included studies and sorted based on date of survey.

\begin{tabular}{|c|c|c|c|c|c|}
\hline Study & Country & Date of survey & $\mathbf{N}^{4}$ & $\begin{array}{c}\text { Target } \\
\text { population }\end{array}$ & $\begin{array}{c}\text { Acceptance } \\
\text { rate }(\%)\end{array}$ \\
\hline Wang et al [31] & Hong Kong & $\begin{array}{l}\text { February and } \\
\text { March, } 2020\end{array}$ & 806 & Nurses & 40.0 \\
\hline Wang et al [32] & China & March, 2020 & 2058 & $\begin{array}{c}\text { General } \\
\text { population }\end{array}$ & 91.3 \\
\hline $\begin{array}{c}\text { Harapan et al } \\
{[33]}\end{array}$ & Indonesia & $\begin{array}{l}\text { March and } \\
\text { April } 2020\end{array}$ & 1359 & $\begin{array}{c}\text { General } \\
\text { population }\end{array}$ & 93.3 \\
\hline Dror et al [34] & Israel & $\begin{array}{l}\text { March and } \\
\text { April } 2020\end{array}$ & 388 & Doctors & 78.1 \\
\hline Detoc et al [35] & France & $\begin{array}{l}\text { March and } \\
\text { April } 2020\end{array}$ & 3259 & $\begin{array}{c}\text { General } \\
\text { population }\end{array}$ & 77.1 \\
\hline Dror et al [34] & Israel & $\begin{array}{l}\text { March and } \\
\text { April } 2020\end{array}$ & 1112 & $\begin{array}{c}\text { General } \\
\text { population }\end{array}$ & 75.0 \\
\hline Kwok et al [36] & Hong Kong & $\begin{array}{l}\text { March and } \\
\text { April } 2020\end{array}$ & 1205 & Nurses & 63.0 \\
\hline Dror et al [34] & Israel & $\begin{array}{l}\text { March and } \\
\text { April } 2020 \\
\end{array}$ & 211 & Nurses & 61.1 \\
\hline Nzaji et al [37] & $\mathrm{DRC}^{1}$ & $\begin{array}{l}\text { March and } \\
\text { April } 2020\end{array}$ & 613 & $\begin{array}{c}\text { Healthcare } \\
\text { workers }\end{array}$ & 27.7 \\
\hline $\begin{array}{c}\text { Gagneux- } \\
\text { Brunon } \text { et al }\end{array}$ & France & $\begin{array}{c}\text { March to July, } \\
2020\end{array}$ & 2047 & $\begin{array}{l}\text { Healthcare } \\
\text { workers }\end{array}$ & 75.9 \\
\hline $\begin{array}{c}\text { Sarasty et al } \\
{[39]}\end{array}$ & Ecuador & April, 2020 & 1050 & $\begin{array}{c}\text { General } \\
\text { population }\end{array}$ & 97.0 \\
\hline Wong et al [40] & Malaysia & April, 2020 & 1159 & $\begin{array}{c}\text { General } \\
\text { population }\end{array}$ & 94.3 \\
\hline $\begin{array}{c}\text { Neumann-Böh } \\
\text { me et al [28] }\end{array}$ & Denmark & April, 2020 & 1000 & $\begin{array}{c}\text { General } \\
\text { population }\end{array}$ & 80.0 \\
\hline $\begin{array}{l}\text { Neumann-Böh } \\
\text { me et al [28] }\end{array}$ & $\mathrm{UK}^{2}$ & April, 2020 & 1000 & $\begin{array}{c}\text { General } \\
\text { population }\end{array}$ & 79.0 \\
\hline $\begin{array}{l}\text { Neumann-Böh } \\
\text { me et al [28] }\end{array}$ & Italy & April, 2020 & 1500 & $\begin{array}{c}\text { General } \\
\text { population }\end{array}$ & 77.3 \\
\hline Ward et al [41] & France & April, 2020 & 5018 & $\begin{array}{c}\text { General } \\
\text { population }\end{array}$ & 76.0 \\
\hline $\begin{array}{l}\text { Neumann-Böh } \\
\text { me et al [28] }\end{array}$ & Portugal & April, 2020 & 1000 & $\begin{array}{c}\text { General } \\
\text { population }\end{array}$ & 75.0 \\
\hline $\begin{array}{c}\text { Neumann-Böh } \\
\text { me et al [28] }\end{array}$ & Netherland & April, 2020 & 1000 & $\begin{array}{c}\text { General } \\
\text { population }\end{array}$ & 73.0 \\
\hline $\begin{array}{l}\text { Neumann-Böh } \\
\text { me et al [28] }\end{array}$ & Germany & April, 2020 & 1000 & $\begin{array}{c}\text { General } \\
\text { population }\end{array}$ & 70.0 \\
\hline $\begin{array}{l}\text { Neumann-Böh } \\
\text { me et al [28] }\end{array}$ & France & April, 2020 & 1000 & $\begin{array}{c}\text { General } \\
\text { population }\end{array}$ & 62.0 \\
\hline Fisher et al [42] & US $^{3}$ & April, 2020 & 1003 & $\begin{array}{c}\text { General } \\
\text { population }\end{array}$ & 56.9 \\
\hline $\begin{array}{c}\text { Salali \& Uysal } \\
{[43]}\end{array}$ & UK & May, 2020 & 1088 & $\begin{array}{c}\text { General } \\
\text { population }\end{array}$ & 86.0 \\
\hline Lin et al [44] & China & May, 2020 & 3541 & $\begin{array}{c}\text { General } \\
\text { population }\end{array}$ & 83.5 \\
\hline Taylor et al [45] & Canada & May, 2020 & 1902 & $\begin{array}{c}\text { General } \\
\text { population }\end{array}$ & 80.0 \\
\hline Taylor et al [45] & US & May, 2020 & 1772 & $\begin{array}{c}\text { General } \\
\text { population }\end{array}$ & 75.0 \\
\hline $\begin{array}{c}\text { Salali \& Uysal } \\
\text { [43] }\end{array}$ & Turkey & May, 2020 & 3936 & $\begin{array}{c}\text { General } \\
\text { population }\end{array}$ & 69.0 \\
\hline Reiter et al [46] & US & May, 2020 & 2006 & $\begin{array}{c}\text { General } \\
\text { population }\end{array}$ & 68.5 \\
\hline Malik et al [47] & US & May, 2020 & 672 & $\begin{array}{c}\text { General } \\
\text { population }\end{array}$ & 67.0 \\
\hline $\begin{array}{c}\text { Lazarus et al } \\
{[27]}\end{array}$ & China & June, 2020 & 712 & $\begin{array}{c}\text { General } \\
\text { population }\end{array}$ & 88.6 \\
\hline $\begin{array}{c}\text { Barello et al } \\
{[48]}\end{array}$ & Italy & June, 2020 & 735 & $\begin{array}{c}\text { University } \\
\text { students }\end{array}$ & 86.1 \\
\hline
\end{tabular}




\begin{tabular}{|c|c|c|c|c|c|}
\hline $\begin{array}{c}\text { Lazarus et al } \\
{[27]}\end{array}$ & Brazil & June, 2020 & 717 & $\begin{array}{c}\text { General } \\
\text { population }\end{array}$ & 85.4 \\
\hline $\begin{array}{c}\text { Lazarus et al } \\
{[27]}\end{array}$ & South Africa & June, 2020 & 619 & $\begin{array}{c}\text { General } \\
\text { population }\end{array}$ & 81.6 \\
\hline $\begin{array}{c}\text { Lazarus et al } \\
{[27]}\end{array}$ & South Korea & June, 2020 & 752 & $\begin{array}{c}\text { General } \\
\text { population }\end{array}$ & 79.8 \\
\hline $\begin{array}{c}\text { Lazarus et al } \\
{[27]}\end{array}$ & Mexico & June, 2020 & 699 & $\begin{array}{c}\text { General } \\
\text { population }\end{array}$ & 76.3 \\
\hline $\begin{array}{c}\text { Lazarus et al } \\
{[27]}\end{array}$ & US & June, 2020 & 773 & $\begin{array}{c}\text { General } \\
\text { population }\end{array}$ & 75.4 \\
\hline $\begin{array}{c}\text { Lazarus et al } \\
{[27]}\end{array}$ & India & June, 2020 & 742 & $\begin{array}{c}\text { General } \\
\text { population }\end{array}$ & 74.5 \\
\hline $\begin{array}{c}\text { Lazarus et al } \\
{[27]}\end{array}$ & Spain & June, 2020 & 748 & $\begin{array}{c}\text { General } \\
\text { population }\end{array}$ & 74.3 \\
\hline $\begin{array}{c}\text { Lazarus et al } \\
{[27]}\end{array}$ & Ecuador & June, 2020 & 741 & $\begin{array}{c}\text { General } \\
\text { population }\end{array}$ & 71.9 \\
\hline $\begin{array}{c}\text { Lazarus et al } \\
{[27]}\end{array}$ & UK & June, 2020 & 768 & $\begin{array}{c}\text { General } \\
\text { population }\end{array}$ & 71.5 \\
\hline $\begin{array}{c}\text { Lazarus et al } \\
{[27]}\end{array}$ & Italy & June, 2020 & 736 & $\begin{array}{c}\text { General } \\
\text { population }\end{array}$ & 70.8 \\
\hline $\begin{array}{c}\text { Lazarus et al } \\
{[27]}\end{array}$ & Canada & June, 2020 & 707 & $\begin{array}{c}\text { General } \\
\text { population }\end{array}$ & 68.7 \\
\hline $\begin{array}{c}\text { Lazarus et al } \\
{[27]}\end{array}$ & Germany & June, 2020 & 722 & $\begin{array}{c}\text { General } \\
\text { population }\end{array}$ & 68.4 \\
\hline $\begin{array}{c}\text { Lazarus et al } \\
{[27]}\end{array}$ & Singapore & June, 2020 & 655 & $\begin{array}{c}\text { General } \\
\text { population }\end{array}$ & 67.9 \\
\hline $\begin{array}{c}\text { Lazarus et al } \\
{[27]}\end{array}$ & Sweden & June, 2020 & 650 & $\begin{array}{c}\text { General } \\
\text { population }\end{array}$ & 65.2 \\
\hline $\begin{array}{c}\text { Lazarus et al } \\
{[27]}\end{array}$ & Nigeria & June, 2020 & 670 & $\begin{array}{c}\text { General } \\
\text { population }\end{array}$ & 65.2 \\
\hline $\begin{array}{c}\text { Lazarus et al } \\
{[27]}\end{array}$ & France & June, 2020 & 669 & $\begin{array}{c}\text { General } \\
\text { population }\end{array}$ & 58.9 \\
\hline $\begin{array}{c}\text { Lazarus et al } \\
{[27]}\end{array}$ & Poland & June, 2020 & 666 & $\begin{array}{c}\text { General } \\
\text { population }\end{array}$ & 56.3 \\
\hline $\begin{array}{c}\text { Lazarus et al } \\
{[27]}\end{array}$ & Russia & June, 2020 & 680 & $\begin{array}{c}\text { General } \\
\text { population }\end{array}$ & 54.9 \\
\hline $\begin{array}{c}\text { Rhodes et al } \\
{[49]}\end{array}$ & Australia & June, 2020 & 2018 & $\begin{array}{c}\text { Parents and } \\
\text { guardians }\end{array}$ & 77.3 \\
\hline Bell et al [50] & UK & July, 2020 & 1252 & $\begin{array}{c}\text { Parents and } \\
\text { guardians }\end{array}$ & 90.1 \\
\hline $\begin{array}{c}\text { Sherman et al } \\
{[51]}\end{array}$ & UK & July, 2020 & 1500 & $\begin{array}{c}\text { General } \\
\text { population }\end{array}$ & 64.0 \\
\hline Zhang et al [52] & China & $\begin{array}{c}\text { September, } \\
2020\end{array}$ & 1052 & $\begin{array}{c}\text { Parents and } \\
\text { guardians }\end{array}$ & 72.6 \\
\hline Gretch et al [30] & Malta & $\begin{array}{c}\text { September, } \\
2020\end{array}$ & 123 & $\begin{array}{l}\text { GPs and GP } \\
\text { trainees }\end{array}$ & 61.8 \\
\hline $\begin{array}{c}\text { La Vecchia et al } \\
{[53]}\end{array}$ & Italy & $\begin{array}{c}\text { September, } \\
2020\end{array}$ & 1055 & $\begin{array}{c}\text { General } \\
\text { population }\end{array}$ & 53.7 \\
\hline Gretch et al [54] & Malta & $\begin{array}{l}\text { September, } \\
2020\end{array}$ & 1002 & $\begin{array}{l}\text { Healthcare } \\
\text { workers }\end{array}$ & 52.0 \\
\hline $\begin{array}{c}\text { Gretch \& Gauci } \\
{[55]}\end{array}$ & Malta & $\begin{array}{c}\text { September, } \\
2020\end{array}$ & 852 & $\begin{array}{l}\text { University } \\
\text { students }\end{array}$ & 44.2 \\
\hline $\begin{array}{c}\text { Freeman et al } \\
{[29]}\end{array}$ & UK & $\begin{array}{c}\text { September and } \\
\text { October, } 2020\end{array}$ & 5114 & $\begin{array}{c}\text { General } \\
\text { population }\end{array}$ & 71.7 \\
\hline $\begin{array}{l}\text { Al-Mohaithef } \\
\text { \& Badhi [56] }\end{array}$ & Saudi Arabia & Unknown & 992 & $\begin{array}{c}\text { General } \\
\text { population }\end{array}$ & 64.7 \\
\hline Sallam et al [26] & Jordan & $\begin{array}{l}\text { December, } \\
2020\end{array}$ & 2173 & $\begin{array}{c}\text { General } \\
\text { population }\end{array}$ & 28.4 \\
\hline Sallam et al [26] & Kuwait & $\begin{array}{l}\text { December, } \\
2020\end{array}$ & 771 & $\begin{array}{c}\text { General } \\
\text { population }\end{array}$ & 23.6 \\
\hline
\end{tabular}

${ }^{1}$ DRC: The Democratic Republic of the Congo; ${ }^{2}$ UK: United Kingdom; ${ }^{3}$ US: United States; ${ }^{4}$ N: Number. 


\subsection{Rates of COVID-19 vaccine acceptance}

The results of COVID-19 vaccine acceptance rates in different studies included in this review and stratified by country are shown in (Table 1). Classified per study, the highest vaccine acceptance rates ( $>90 \%)$ among the general public were found in four studies from Ecuador (97.0\%), Malaysia (94.3\%), Indonesia (93.3\%) and China (91.3\%). On the contrary, the lowest vaccine acceptance rates $(<60 \%)$ among the general public were found in seven studies from Kuwait (23.6\%), Jordan (28.4\%), Italy (53.7), Russia (54.9\%), Poland (56.3\%), US (56.9\%), and France $(58.9 \%)$.

For the eight studies conducted among healthcare workers, three surveys reported vaccine acceptance rates below $60 \%$, with the highest rate being among doctors in Israel $(78.1 \%)$ and the lowest vaccine acceptance rate $(27.7 \%)$ reported among healthcare workers in the Democratic Republic of the Congo (DRC).

For the three studies conducted among parents/guardians, the vaccine acceptance rates were more than $70 \%$. For the two studies among University students, the vaccine acceptance rate was $44.2 \%$ in Malta and $86.1 \%$ in Italy.

\subsection{Changes in COVID-19 vaccine acceptance over time in countries with multiple survey studies}

In countries with multiple surveys over time, the following changes in COVID-19 vaccine acceptance rates were observed: In UK, the vaccine acceptance rate was $79.0 \%$ in April, $86.0 \%$ in May, $71.5 \%$ in June, $64.0 \%$ in July and $71.7 \%$ in September/October. In France, the vaccine acceptance rate ranged from $62.0 \%$ to $77.1 \%$ in March/April and was $58.9 \%$ in June. In Italy, the vaccine acceptance rate was 77.3\% in April, $70.8 \%$ in June and reached $53.7 \%$ in September.

For the vaccine acceptance rates in US, it was $56.9 \%$ in April, and ranged from $67.0 \%$ to $75.0 \%$ in May, and reached $75.4 \%$ in June. In China, three studies reported high rates of vaccine acceptance with the first study that reported a vaccine acceptance rate of $91.3 \%$ in March, the second study reported a rate of $83.5 \%$ in May and the third study reported a rate of $88.6 \%$ in June.

\section{Discussion}

Vaccine hesitancy is an old phenomenon that represents a serious threat to the global health, as shown in resurgence of some infectious diseases (e.g. outbreaks of measles and pertussis) [57-61]. The huge leaps in developing efficacious and safe COVID-19 vaccines within a short period were unprecedented [62-64]. Nevertheless, COVID-19 vaccine hesitancy can be the limiting step in the global efforts to control the current pandemic with its negative health and socio-economic effects $[24,65,66]$.

Assessing the level of population immunity necessary to limit the pathogen spread is dependent on the basic reproductive number for that infectious disease [67]. The latest estimates on COVID-19, pointed to the range of $60-75 \%$ immune individuals that would be necessary to halt the forward transmission of the virus and community spread of the virus [68-70]. Vaccine cost, effectiveness and duration of protection appear as important factors to achieve such a goal $[64,71,72]$. However, vaccine hesitancy can be a decisive factor for successful control of the current COVID-19 pandemic [24,73]. Thus, estimates of vaccine acceptance rates can be helpful to plan actions and intervention measures necessary to increase the awareness and assure people about the safety and benefits of vaccines, which in turn would help to control virus spread and alleviate the negative effects of this unprecedented pandemic [74,75].

In this review, a large variability in COVID-19 vaccine acceptance rates was found. However, certain patterns can be deduced based on descriptive analysis of the reported vaccine acceptance rates. First, in East and South East Asia, the overall acceptance rates among the general public were relatively high. This includes more than $90 \%$ acceptance rates in Indonesia, Malaysia and one study from China [32,33,40]. Another two surveys 
on the general public in China reported vaccine acceptance rates of more than $80 \%$, with an additional survey in South Korea that reported a rate of $79.8 \%$ [27,44]. A later survey from Shenzhen, China by Zhang et al, that surveyed parents/guardians who were faculty workers, on their acceptability of children COVID-19 vaccination reported a lower rate of $72.5 \%$ compared to the previous studies [52]. Similarly, an online survey on Australian parents showed an acceptance rate of $77.3 \%$ [49]. The lowest COVID-19 vaccine acceptance rate among the general public in the region was reported by Lazarus et al, in Singapore $(67.9 \%)$ [27]. The relatively high rates of vaccine acceptance in the region were attributed to strong trust in governments [27]. Additionally, the only survey in India reported a vaccine acceptance rate of $74.5 \%$ [27].

However, two studies that dated back to early part of the pandemic (February and March) among nurses in Hong Kong reported low rates of COVID-19 acceptance (40.0\% and $63.0 \%$ ) [31,36]. Likewise, Kabamba Nzaji et al reported a very low rate of COVID-19 vaccine acceptance among healthcare workers in the DRC (27.7\%) [37]. This issue is of high concern considering the front-line position of healthcare workers in fighting the spread and effects of COVID-19 pandemic, which put them at a higher risk of infection, and hence their higher need for protective measures [76-78].

Also, the vaccine acceptance rates were relatively high in Latin America, where results from Brazil and Ecuador reported more than $70 \%$ acceptance rates [27,39]. This was also seen in the survey from Mexico with a vaccine acceptance rate of $76.3 \%$ [27].

In Europe, the results were largely variable, with countries around the Mediterranean reporting vaccine acceptance rates as low as 53.7\% in Italy, 58.9\% in France; while no surveys among general public in Malta were found $[27,53]$. However, the vaccine acceptance rates among students and healthcare workers in Malta were $44.2 \%$ and 52.0\%, respectively [54,55]. Variable results were also reported in other European countries with rates as high as $80.0 \%$ in Denmark, and as low as $56.3 \%$ in Poland $[27,28]$. The vaccine acceptance rates were even lower in Russia (54.9\%), which needs further evaluation considering the heavy toll of COVID-19 on the country [11,27]. Variability in vaccine acceptance rates was also seen in UK, US and Canada over the course of the pandemic $[42,43,45,46,51]$.

The Middle East was among the regions with the lowest vaccine acceptance rates globally. The acceptance rate was the lowest in Kuwait (23.6\%), Jordan (28.4\%), Saudi Arabia $(64.7 \%)$ and Turkey $(69.0 \%)[26,43,56]$. On the other hand, the highest vaccine acceptance rate was reported in Israel $(75.0 \%)$, however; this rate was much lower among nurses surveyed in the same study (61.1\%) [34].

Finally, only two surveys among the general public in African countries were found that reported an acceptance rate of $81.6 \%$ in South Africa and 65.2\% in Nigeria [27]. Thus, more studies are recommended in Africa to address COVID-19 vaccine hesitancy in the continent. Besides Africa, more studies are needed from Central Asia, Eastern Europe, Central and South America to reach reliable conclusions about the scope of COVID-19 vaccine hesitancy around the globe.

\section{Conclusions}

Large variability in COVID-19 vaccine acceptance rates was reported in different countries and regions of the world. A sizable number of studies reported COVID-19 acceptance rates below $60 \%$, which would pose a serious problem for efforts to control the current COVID-19 pandemic. Low COVID-19 vaccine acceptance rates were more pronounced in the Middle East, Eastern Europe and Russia. High acceptance rates in East and South East Asia would help to achieve proper control of the pandemic. More studies are recommended to assess the attitude of general public and healthcare workers in Africa, Central Asia and the Middle East besides Central and South America. Such studies would help to evaluate COVID-19 vaccine hesitancy and its potential consequences in these regions, and around the globe. 
Funding: This research received no external funding.

Institutional Review Board Statement: Ethical approval is not applicable for this systematic review since data from previous published studies in which informed consent was obtained by primary investigators was analyzed.

Data Availability Statement: Data supporting this systematic review are available in the reference section. In addition, the analyzed data that were used during the current systematic review are available from the author on reasonable request.

Acknowledgments: NA.

Conflicts of Interest: The author declares that there is no conflict of interest.

\section{References}

1. MacDonald, N.E.; Sage Working Group on Vaccine Hesitancy. Vaccine hesitancy: Definition, scope and determinants. Vaccine 2015, 33, 4161-4164, doi:10.1016/j.vaccine.2015.04.036.

2. SAGE Working Group on Vaccine Hesitancy. Report of the SAGE Working Group on Vaccine Hesitancy,. Availabe online: https://www.who.int/immunization/sage/meetings/2014/october/1_Report_WORKING_GROUP_vaccine_hesitancy_final. pdf (accessed on 26-12-2020).

3. Gowda, C.; Dempsey, A.F. The rise (and fall?) of parental vaccine hesitancy. Hum Vaccin Immunother 2013, 9, 1755-1762, doi:10.4161/hv.25085.

4. Kumar, D.; Chandra, R.; Mathur, M.; Samdariya, S.; Kapoor, N. Vaccine hesitancy: understanding better to address better. Isr J Health Policy Res 2016, 5, 2, doi:10.1186/s13584-016-0062-y.

5. Daley, M.F.; Narwaney, K.J.; Shoup, J.A.; Wagner, N.M.; Glanz, J.M. Addressing Parents' Vaccine Concerns: A Randomized Trial of a Social Media Intervention. Am J Prev Med 2018, 55, 44-54, doi:10.1016/j.amepre.2018.04.010.

6. Arede, M.; Bravo-Araya, M.; Bouchard, E.; Singh Gill, G.; Plajer, V.; Shehraj, A.; Adam Shuaib, Y. Combating Vaccine Hesitancy: Teaching the Next Generation to Navigate Through the Post Truth Era. Front Public Health 2018, 6, 381, doi:10.3389/fpubh.2018.00381.

7. Dube, E.; Vivion, M.; MacDonald, N.E. Vaccine hesitancy, vaccine refusal and the anti-vaccine movement: influence, impact and implications. Expert Rev Vaccines 2015, 14, 99-117, doi:10.1586/14760584.2015.964212.

8. Salmon, D.A.; Dudley, M.Z.; Glanz, J.M.; Omer, S.B. Vaccine Hesitancy: Causes, Consequences, and a Call to Action. Am J Prev Med 2015, 49, S391-398, doi:10.1016/j.amepre.2015.06.009.

9. Larson, H.J.; Cooper, L.Z.; Eskola, J.; Katz, S.L.; Ratzan, S. Addressing the vaccine confidence gap. Lancet 2011, 378, 526-535, doi:10.1016/S0140-6736(11)60678-8.

10. Olson, O.; Berry, C.; Kumar, N. Addressing Parental Vaccine Hesitancy towards Childhood Vaccines in the United States: A Systematic Literature Review of Communication Interventions and Strategies. Vaccines (Basel) 2020, 8, doi:10.3390/vaccines8040590.

11. Worldometer. COVID-19 CORONAVIRUS PANDEMIC. Availabe online: https://www.worldometers.info/coronavirus/ (accessed on 27-12-2020).

12. World Health Organization. COVID-19 weekly epidemiological update, 22 December 2020. Availabe online: https://www.who.int/publications/m/item/weekly-epidemiological-update---22-december-2020 (accessed on 26-12-2020).

13. Prem, K.; Liu, Y.; Russell, T.W.; Kucharski, A.J.; Eggo, R.M.; Davies, N.; Centre for the Mathematical Modelling of Infectious Diseases, C.-W.G.; Jit, M.; Klepac, P. The effect of control strategies to reduce social mixing on outcomes of the COVID-19 epidemic in Wuhan, China: a modelling study. Lancet Public Health 2020, 5, e261-e270, doi:10.1016/S2468-2667(20)30073-6.

14. Viner, R.M.; Russell, S.J.; Croker, H.; Packer, J.; Ward, J.; Stansfield, C.; Mytton, O.; Bonell, C.; Booy, R. School closure and management practices during coronavirus outbreaks including COVID-19: a rapid systematic review. Lancet Child Adolesc Health 2020, 4, 397-404, doi:10.1016/S2352-4642(20)30095-X.

15. Feng, S.; Shen, C.; Xia, N.; Song, W.; Fan, M.; Cowling, B.J. Rational use of face masks in the COVID-19 pandemic. The Lancet Respiratory Medicine 2020, 8, 434-436.

16. Korber, B.; Fischer, W.M.; Gnanakaran, S.; Yoon, H.; Theiler, J.; Abfalterer, W.; Hengartner, N.; Giorgi, E.E.; Bhattacharya, T.; Foley, B. Tracking changes in SARS-CoV-2 Spike: evidence that D614G increases infectivity of the COVID-19 virus. Cell 2020, 182, 812-827. e819.

17. Grubaugh, N.D.; Hanage, W.P.; Rasmussen, A.L. Making sense of mutation: what D614G means for the COVID-19 pandemic remains unclear. Cell 2020, 182, 794-795.

18. Sallam, M.; Ababneh, N.; Dababseh, D.; Bakri, F.; Mahafzah, A. Temporal increase in D614G mutation of SARS-CoV-2 in the Middle East and North Africa: Phylogenetic and mutation analysis study. medRxiv 2020.

19. European Centre for Disease Prevention and Control. Threat Assessment Brief: Rapid increase of a SARS-CoV-2 variant with multiple spike protein mutations observed in the United Kingdom. Availabe online: 
https:/www.ecdc.europa.eu/en/publications-data/threat-assessment-brief-rapid-increase-sars-cov-2-variant-unitedkingdom (accessed on 26-12-2020).

20. Nicola, M.; Alsafi, Z.; Sohrabi, C.; Kerwan, A.; Al-Jabir, A.; Iosifidis, C.; Agha, M.; Agha, R. The socio-economic implications of the coronavirus pandemic (COVID-19): A review. Int J Surg 2020, 78, 185-193, doi:10.1016/j.ijsu.2020.04.018.

21. Calina, D.; Docea, A.O.; Petrakis, D.; Egorov, A.M.; Ishmukhametov, A.A.; Gabibov, A.G.; Shtilman, M.I.; Kostoff, R.; Carvalho, F.; Vinceti, M., et al. Towards effective COVID19 vaccines: Updates, perspectives and challenges (Review). Int $J$ Mol Med 2020, 46, 3-16, doi:10.3892/ijmm.2020.4596.

22. Conte, C.; Sogni, F.; Affanni, P.; Veronesi, L.; Argentiero, A.; Esposito, S. Vaccines against Coronaviruses: The State of the Art. Vaccines (Basel) 2020, 8, doi:10.3390/vaccines8020309.

23. World Health Organization (WHO). Draft landscape of COVID-19 candidate vaccines. Availabe online: https://www.who.int/publications/m/item/draft-landscape-of-covid-19-candidate-vaccines (accessed on 26-12-2020). Harrison, E.A.; Wu, J.W. Vaccine confidence in the time of COVID-19. Eur J Epidemiol 2020, 35, 325-330, doi:10.1007/s10654020-00634-3.

25. Moher, D.; Liberati, A.; Tetzlaff, J.; Altman, D.G.; Group, P. Preferred reporting items for systematic reviews and metaanalyses: the PRISMA statement. PLoS Med 2009, 6, e1000097, doi:10.1371/journal.pmed.1000097.

26. Sallam, M.; Dababseh, D.; Eid, H.; Al-Mahzoum, K.; Al-Haidar, A.; Taim, D.; Yaseen, A.; Ababneh, N.A.; Bakri, F.G.; Mahafzah, A. High rates of COVID-19 vaccine hesitancy and its association with conspiracy beliefs: A study in Jordan and Kuwait among other Arab countries. 2020.

27. Lazarus, J.V.; Ratzan, S.C.; Palayew, A.; Gostin, L.O.; Larson, H.J.; Rabin, K.; Kimball, S.; El-Mohandes, A. A global survey of potential acceptance of a COVID-19 vaccine. Nat Med 2020, 10.1038/s41591-020-1124-9, doi:10.1038/s41591-020-1124-9.

28. Neumann-Böhme, S.; Varghese, N.E.; Sabat, I.; Barros, P.P.; Brouwer, W.; van Exel, J.; Schreyögg, J.; Stargardt, T. Once we have it, will we use it? A European survey on willingness to be vaccinated against COVID-19. Springer: 2020.

29. Freeman, D.; Loe, B.S.; Chadwick, A.; Vaccari, C.; Waite, F.; Rosebrock, L.; Jenner, L.; Petit, A.; Lewandowsky, S.; Vanderslott, S., et al. COVID-19 Vaccine Hesitancy in the UK: The Oxford Coronavirus Explanations, Attitudes, and Narratives Survey (OCEANS) II. Psychol Med 2020, 10.1017/S0033291720005188, 1-34, doi:10.1017/S0033291720005188.

30. Grech, V.; Bonnici, J.; Zammit, D. Vaccine hesitancy in Maltese family physicians and their trainees vis-a-vis influenza and novel COVID-19 vaccination. Early Hum Dev 2020, 10.1016/j.earlhumdev.2020.105259, 105259, doi:10.1016/j.earlhumdev.2020.105259.

31. Wang, K.; Wong, E.L.Y.; Ho, K.F.; Cheung, A.W.L.; Chan, E.Y.Y.; Yeoh, E.K.; Wong, S.Y.S. Intention of nurses to accept coronavirus disease 2019 vaccination and change of intention to accept seasonal influenza vaccination during the coronavirus disease 2019 pandemic: A cross-sectional survey. Vaccine 2020, 38, 7049-7056, doi:10.1016/j.vaccine.2020.09.021.

32. Wang, J.; Jing, R.; Lai, X.; Zhang, H.; Lyu, Y.; Knoll, M.D.; Fang, H. Acceptance of COVID-19 Vaccination during the COVID19 Pandemic in China. Vaccines (Basel) 2020, 8, doi:10.3390/vaccines8030482.

33. Harapan, H.; Wagner, A.L.; Yufika, A.; Winardi, W.; Anwar, S.; Gan, A.K.; Setiawan, A.M.; Rajamoorthy, Y.; Sofyan, H.; Mudatsir, M. Acceptance of a COVID-19 Vaccine in Southeast Asia: A Cross-Sectional Study in Indonesia. Front Public Health 2020, 8, 381, doi:10.3389/fpubh.2020.00381.

34. Dror, A.A.; Eisenbach, N.; Taiber, S.; Morozov, N.G.; Mizrachi, M.; Zigron, A.; Srouji, S.; Sela, E. Vaccine hesitancy: the next challenge in the fight against COVID-19. Eur J Epidemiol 2020, 35, 775-779, doi:10.1007/s10654-020-00671-y.

35. Detoc, M.; Bruel, S.; Frappe, P.; Tardy, B.; Botelho-Nevers, E.; Gagneux-Brunon, A. Intention to participate in a COVID-19 vaccine clinical trial and to get vaccinated against COVID-19 in France during the pandemic. Vaccine 2020, 38, 7002-7006, doi:10.1016/j.vaccine.2020.09.041.

36. Kwok, K.O.; Li, K.K.; Wei, W.I.; Tang, A.; Wong, S.Y.S.; Lee, S.S. Influenza vaccine uptake, COVID-19 vaccination intention and vaccine hesitancy among nurses: A survey. Int J Nurs Stud 2020, 114, 103854, doi:10.1016/j.ijnurstu.2020.103854.

37. Kabamba Nzaji, M.; Kabamba Ngombe, L.; Ngoie Mwamba, G.; Banza Ndala, D.B.; Mbidi Miema, J.; Luhata Lungoyo, C.; Lora Mwimba, B.; Cikomola Mwana Bene, A.; Mukamba Musenga, E. Acceptability of Vaccination Against COVID-19 Among Healthcare Workers in the Democratic Republic of the Congo. Pragmat Obs Res 2020, 11, 103-109, doi:10.2147/POR.S271096.

38. Gagneux-Brunon, A.; Detoc, M.; Bruel, S.; Tardy, B.; Rozaire, O.; Frappe, P.; Botelho-Nevers, E. Intention to get vaccinations against COVID-19 in French healthcare workers during the first pandemic wave: a cross sectional survey. J Hosp Infect 2020, 10.1016/j.jhin.2020.11.020, doi:10.1016/j.jhin.2020.11.020.

39. Sarasty, O.; Carpio, C.E.; Hudson, D.; Guerrero-Ochoa, P.A.; Borja, I. The demand for a COVID-19 vaccine in Ecuador. Vaccine 2020, 38, 8090-8098, doi:10.1016/j.vaccine.2020.11.013.

40. Wong, L.P.; Alias, H.; Wong, P.F.; Lee, H.Y.; AbuBakar, S. The use of the health belief model to assess predictors of intent to receive the COVID-19 vaccine and willingness to pay. Hum Vaccin Immunother 2020, 16, 2204-2214, doi:10.1080/21645515.2020.1790279.

41. Ward, J.K.; Alleaume, C.; Peretti-Watel, P.; Group, C. The French public's attitudes to a future COVID-19 vaccine: The politicization of a public health issue. Soc Sci Med 2020, 265, 113414, doi:10.1016/j.socscimed.2020.113414. 
42. Fisher, K.A.; Bloomstone, S.J.; Walder, J.; Crawford, S.; Fouayzi, H.; Mazor, K.M. Attitudes Toward a Potential SARS-CoV2 Vaccine : A Survey of U.S. Adults. Ann Intern Med 2020, 173, 964-973, doi:10.7326/M20-3569.

43. Salali, G.D.; Uysal, M.S. COVID-19 vaccine hesitancy is associated with beliefs on the origin of the novel coronavirus in the UK and Turkey. Psychol Med 2020, 10.1017/S0033291720004067, 1-3, doi:10.1017/S0033291720004067.

44. Lin, Y.; Hu, Z.; Zhao, Q.; Alias, H.; Danaee, M.; Wong, L.P. Understanding COVID-19 vaccine demand and hesitancy: A nationwide online survey in China. PLoS Negl Trop Dis 2020, 14, e0008961, doi:10.1371/journal.pntd.0008961.

45. Taylor, S.; Landry, C.A.; Paluszek, M.M.; Groenewoud, R.; Rachor, G.S.; Asmundson, G.J.G. A Proactive Approach for Managing COVID-19: The Importance of Understanding the Motivational Roots of Vaccination Hesitancy for SARS-CoV2. Front Psychol 2020, 11, 575950, doi:10.3389/fpsyg.2020.575950.

46. Reiter, P.L.; Pennell, M.L.; Katz, M.L. Acceptability of a COVID-19 vaccine among adults in the United States: How many people would get vaccinated? Vaccine 2020, 38, 6500-6507, doi:10.1016/j.vaccine.2020.08.043.

47. Malik, A.A.; McFadden, S.M.; Elharake, J.; Omer, S.B. Determinants of COVID-19 vaccine acceptance in the US. EClinicalMedicine 2020, 26, 100495, doi:10.1016/j.eclinm.2020.100495.

48. Barello, S.; Nania, T.; Dellafiore, F.; Graffigna, G.; Caruso, R. 'Vaccine hesitancy'among university students in Italy during the COVID-19 pandemic. European journal of epidemiology 2020, 35, 781-783.

49. Rhodes, A.; Hoq, M.; Measey, M.A.; Danchin, M. Intention to vaccinate against COVID-19 in Australia. Lancet Infect Dis 2020, 10.1016/S1473-3099(20)30724-6, doi:10.1016/S1473-3099(20)30724-6.

50. Bell, S.; Clarke, R.; Mounier-Jack, S.; Walker, J.L.; Paterson, P. Parents' and guardians' views on the acceptability of a future COVID-19 vaccine: A multi-methods study in England. Vaccine 2020, 38, 7789-7798, doi:10.1016/j.vaccine.2020.10.027.

51. Sherman, S.M.; Smith, L.E.; Sim, J.; Amlot, R.; Cutts, M.; Dasch, H.; Rubin, G.J.; Sevdalis, N. COVID-19 vaccination intention in the UK: results from the COVID-19 vaccination acceptability study (CoVAccS), a nationally representative cross-sectional survey. Hum Vaccin Immunother 2020, 10.1080/21645515.2020.1846397, 1-10, doi:10.1080/21645515.2020.1846397.

52. Zhang, K.C.; Fang, Y.; Cao, H.; Chen, H.; Hu, T.; Chen, Y.Q.; Zhou, X.; Wang, Z. Parental acceptability of COVID-19 vaccination for children under the age of 18 years in China: cross-sectional online survey. JMIR Pediatr Parent 2020, 10.2196/24827, doi:10.2196/24827.

53. La Vecchia, C.; Negri, E.; Alicandro, G.; Scarpino, V. Attitudes towards influenza vaccine and a potential COVID-19 vaccine in Italy and differences across occupational groups, September 2020. Med Lav 2020, 111, 445-448, doi:10.23749/mdl.v111i6.10813.

54. Grech, V.; Gauci, C.; Agius, S. Vaccine hesitancy among Maltese healthcare workers toward influenza and novel COVID-19 vaccination. Early Hum Dev 2020, 10.1016/j.earlhumdev.2020.105213, 105213, doi:10.1016/j.earlhumdev.2020.105213.

55. Grech, V.; Gauci, C. Vaccine hesitancy in the University of Malta Faculties of Health Sciences, Dentistry and Medicine visa-vis influenza and novel COVID-19 vaccination. Early Hum Dev 2020, 10.1016/j.earlhumdev.2020.105258, 105258, doi:10.1016/j.earlhumdev.2020.105258.

56. Al-Mohaithef, M.; Padhi, B.K. Determinants of COVID-19 Vaccine Acceptance in Saudi Arabia: A Web-Based National Survey. J Multidiscip Healthc 2020, 13, 1657-1663, doi:10.2147/JMDH.S276771.

57. Phadke, V.K.; Bednarczyk, R.A.; Salmon, D.A.; Omer, S.B. Association Between Vaccine Refusal and Vaccine-Preventable Diseases in the United States: A Review of Measles and Pertussis. JAMA 2016, 315, 1149-1158, doi:10.1001/jama.2016.1353.

58. Benecke, O.; DeYoung, S.E. Anti-Vaccine Decision-Making and Measles Resurgence in the United States. Glob Pediatr Health 2019, 6, 2333794X19862949, doi:10.1177/2333794X19862949.

59. Gangarosa, E.J.; Galazka, A.M.; Wolfe, C.R.; Phillips, L.M.; Gangarosa, R.E.; Miller, E.; Chen, R.T. Impact of anti-vaccine movements on pertussis control: the untold story. Lancet 1998, 351, 356-361, doi:10.1016/s0140-6736(97)04334-1.

60. Borba, R.C.; Vidal, V.M.; Moreira, L.O. The re-emergency and persistence of vaccine preventable diseases. An Acad Bras Cienc 2015, 87, 1311-1322, doi:10.1590/0001-3765201520140663.

61. Wong, L.P.; Wong, P.F.; AbuBakar, S. Vaccine hesitancy and the resurgence of vaccine preventable diseases: the way forward for Malaysia, a Southeast Asian country. Hum Vaccin Immunother 2020, 16, 1511-1520, doi:10.1080/21645515.2019.1706935.

62. Lurie, N.; Saville, M.; Hatchett, R.; Halton, J. Developing Covid-19 vaccines at pandemic speed. New England Journal of Medicine 2020, 382, 1969-1973.

63. Graham, B.S. Rapid COVID-19 vaccine development. Science 2020, 368, 945-946.

64. Sharma, O.; Sultan, A.A.; Ding, H.; Triggle, C.R. A Review of the Progress and Challenges of Developing a Vaccine for COVID-19. Front Immunol 2020, 11, 585354, doi:10.3389/fimmu.2020.585354.

65. Pogue, K.; Jensen, J.L.; Stancil, C.K.; Ferguson, D.G.; Hughes, S.J.; Mello, E.J.; Burgess, R.; Berges, B.K.; Quaye, A.; Poole, B.D. Influences on Attitudes Regarding Potential COVID-19 Vaccination in the United States. Vaccines (Basel) 2020, 8, doi:10.3390/vaccines8040582.

66. Hamadani, J.D.; Hasan, M.I.; Baldi, A.J.; Hossain, S.J.; Shiraji, S.; Bhuiyan, M.S.A.; Mehrin, S.F.; Fisher, J.; Tofail, F.; Tipu, S.M.U. Immediate impact of stay-at-home orders to control COVID-19 transmission on socioeconomic conditions, food 
insecurity, mental health, and intimate partner violence in Bangladeshi women and their families: an interrupted time series. The Lancet Global Health 2020, 8, e1380-e1389.

67. Ridenhour, B.; Kowalik, J.M.; Shay, D.K. Unraveling r 0: Considerations for public health applications. American journal of public health 2018, 108, S445-S454.

68. Billah, M.A.; Miah, M.M.; Khan, M.N. Reproductive number of coronavirus: A systematic review and meta-analysis based on global level evidence. PLoS One 2020, 15, e0242128, doi:10.1371/journal.pone.0242128.

69. Anderson, R.M.; Vegvari, C.; Truscott, J.; Collyer, B.S. Challenges in creating herd immunity to SARS-CoV-2 infection by mass vaccination. Lancet 2020, 396, 1614-1616, doi:10.1016/S0140-6736(20)32318-7.

70. Britton, T.; Ball, F.; Trapman, P. A mathematical model reveals the influence of population heterogeneity on herd immunity to SARS-CoV-2. Science 2020, 369, 846-849.

71. Wang, J.; Peng, Y.; Xu, H.; Cui, Z.; Williams, R.O., 3rd. The COVID-19 Vaccine Race: Challenges and Opportunities in Vaccine Formulation. AAPS PharmSciTech 2020, 21, 225, doi:10.1208/s12249-020-01744-7.

72. Teerawattananon, Y.; Dabak, S.V. COVID vaccination logistics: five steps to take now. Nature Publishing Group: 2020.

73. Palamenghi, L.; Barello, S.; Boccia, S.; Graffigna, G. Mistrust in biomedical research and vaccine hesitancy: the forefront challenge in the battle against COVID-19 in Italy. European journal of epidemiology 2020, 35, 785-788.

74. Weintraub, R.L.; Subramanian, L.; Karlage, A.; Ahmad, I.; Rosenberg, J. COVID-19 Vaccine To Vaccination: Why Leaders Must Invest In Delivery Strategies Now: Analysis describe lessons learned from past pandemics and vaccine campaigns about the path to successful vaccine delivery for COVID-19. Health Affairs 2020, 10.1377/hlthaff. 2020.01523.

75. Habersaat, K.B.; Betsch, C.; Danchin, M.; Sunstein, C.R.; Böhm, R.; Falk, A.; Brewer, N.T.; Omer, S.B.; Scherzer, M.; Sah, S. Ten considerations for effectively managing the COVID-19 transition. Nature human behaviour 2020, 4, 677-687.

76. Nguyen, L.H.; Drew, D.A.; Graham, M.S.; Joshi, A.D.; Guo, C.-G.; Ma, W.; Mehta, R.S.; Warner, E.T.; Sikavi, D.R.; Lo, C.-H. Risk of COVID-19 among front-line health-care workers and the general community: a prospective cohort study. The Lancet Public Health 2020, 5, e475-e483.

77. Shaukat, N.; Ali, D.M.; Razzak, J. Physical and mental health impacts of COVID-19 on healthcare workers: a scoping review. Int J Emerg Med 2020, 13, 40, doi:10.1186/s12245-020-00299-5.

78. Liu, Q.; Luo, D.; Haase, J.E.; Guo, Q.; Wang, X.Q.; Liu, S.; Xia, L.; Liu, Z.; Yang, J.; Yang, B.X. The experiences of health-care providers during the COVID-19 crisis in China: a qualitative study. Lancet Glob Health 2020, 8, e790-e798, doi:10.1016/S2214109X(20)30204-7. 